\title{
The Study of Investment Preferences of Russians on Individual Investment Accounts
}

\author{
Daria Karpova ${ }^{1}$ and Svetlana Panova ${ }^{2, *}$ \\ ${ }^{1}$ Financial University Under the Government of the Russian Federation, 5 Khromova Street, Apt.166, \\ Moscow, 107392, Russia \\ ${ }^{2}$ Financial University under the Government of the Russian Federation, 1 Kibal'chicha Street, Moscow, \\ 107996, Russia
}

\begin{abstract}
Individual Investment Accounts (IIAs) are assumed to be a tax incentive introduced in the Russian Federation in 2015 aimed to solve the problem of low level of private investors' awareness of the securities market opportunities and small fraction of households' investment in the country's GDP. The existing evidence on such incentive is concerned mostly about the use of international tax incentives and its implementation in Russia, while rare literature provides any background on investment behaviour of the Russians, especially for 3 and more years' time. This paper adds to this point, answering the question about the impact of major sociodemographic factors (including age, gender, marital status, education level and occupation) on the individuals' investment preferences for long-term investment on tax-beneficial accounts, using the data from an anonymous questionnaire study conducted among 200 adult citizens of Russia.
\end{abstract}

Keywords: Tax Incentives, Individual Investment Accounts, Individual Investors, Investment Preferences, Sociodemographic Factors.

\section{INTRODUCTION}

As far as the level of households' participation in the financial market of the country is supposed to be one of the crucial criteria of the good standards of living and the country's financial market maturity, which ensures that households' savings are transformed into investment in the economy of the country (OECD, 1994), the problem of creating favourable conditions for individual investors in terms of market transparency enhancement and tax incentives implementation was emphasised in the Russian Financial Market Development Strategy through to 2020 presented by the Central Bank of Russia in 2008. Among other things, this plan focused on the development of young Russian financial market which suffers from the financial resources undersaturation and dependence on foreign investment inflow (Rot et al., 2002). It was a first official document stating the intention of the Russian Government to change such situation using tax incentives for households, successfully implemented in several developed countries, like USA, UK and Canada at that period of time (Japan joined this list some 5 years later).

In 2015, when the idea of Individual Investment Accounts (IIAs) got its practical realization, Russia was characterized by the lowest level of private investment as a percentage of the country's GDP $(0.2 \%)$,

*Address correspondence to this author at the Department of Financial Markets and Banks, 1 Kibal'chicha Street, Moscow, 107996, Russia;

Tel: +79104807843; E-mail: sveta1763@mail.ru comparing both to its BRICS partners, like China $(5.0 \%)$ and India $(5.0 \%)$, and to the developed countries, including USA (80.0\%) and United Kingdom (30.0\%) (World Bank, 2017). Public authorities, together with the professional market participants' society, are paying a lot of attention to this issue both in terms of its legal elaboration and popularization among the Russians (particularly, this was stated to be the main goal of the largest securities exchange in Russia - Moscow Exchange, for the year of 2017), making researchers also pay extra effort for this phenomenon investigation both in the respect of the Russian peculiarities and existing international evidence.

After 3 years of such accounts' use, a variety of studies have recently examined the issue of international tax incentives use and Individual Investment Accounts' implementation in Russia, while other covered the relation between demographic variables and savings habits of Russians citizens. Still, rare evidence has been provided for investment behaviour of the Russians, especially on the long-term run as Individual Investment Accounts assume. That is why this study attempts to test whether there is any relation between the major sociodemographic characteristics and the investor's habits in case of investing for 3 or more years with such beneficial accounts. That made authors choose the research problem of this paper as the following: what impact do sociodemographic characteristics have on the person's investment preferences for long-term investment on Individual Investment Accounts? 
Since the main goal of the research was getting the picture of potential Individual Investment Accounts users' investment preferences, questionnaires and online questionnaires seemed to be appropriate research methods of obtaining primary information for its deep analysis. The data received during the research was analyzed, using both standard methods of analysis (including cross-tabulating, filtering results, respondent group analysis, etc.) and regression analysis with finding correlations between different groups of analyzed variables.

The paper is aimed to add to the existing literature about Individual Investment Accounts' implementation in Russia, giving a picture of the potential investors who may be interested in investing their money for 3 or more years, as well as outlining investment preferences in terms of such parameters as the expected level of annual return, the currency of investment, the marginal time horizon of investment, the asset categories, etc. Also, it extends existing research on investment habits of the Russians, as such analysis is usually conducted for banking, not investment products or just among existing investors, not potential ones.

The paper's structure goes as following: firstly, it gives a picture of how individual investment accounts work in Russia, secondly - reviewing what have already been written about such incentive, thirdly giving the research methodolory, fourthly - analyzing it in different terms.

\section{FRAMEWORK OF INDIVIDUAL INVESTMENT ACCOUNTS USE IN RUSSIA}

Since the development of any securities market is considered to be related to its saturation by financial recourses of both individuals and corporations, there are several developed countries, including USA and UK, that paid a lot of effort to increase the participation of households as long-term money suppliers, making them invest more with specific tax incentives and longterm beneficial pension and investment accounts. For instance, working as a part of the US pension system for the last 43 years, Individual Retirement Accounts are held by $33.8 \%$ of households, with the amount of 7.5 Trillion Dollars accumulated on such accounts (ici.org, 2017). The UK citizens have an opportunity to open an Individual Saving Account for long-term savings purposes since 1999 , and, as for now, $34.7 \%$ of the country's population (or $58.5 \%$ of households) hold approximately 518 Billion Pounds on these accounts (gov.uk, 2017). Even the youngest in terms of tax beneficial accounts' implementation country of Japan attracted nearly $5.2 \%$ of the Japanese to use Nippon Individual Saving Accounts and make contributions that amounted to 6 Trillion Yen last year (jsda.or.jp, 2017). Such incentives are aimed to cover not only adults (older than 18 years for UK and than 20 years - for Japan), but also teenagers at the age of 16 and older, making young citizens involved as well.

When it comes to the comparison of Russia with such countries, there are foreseen to be less than $1 \%$ of the overall population acquainted to the securities market and nearly $0.1 \%$ of all Russians actively use it for capital allocation. That is why, since the Russians are tend to be unfamiliar with the securities market opportunities for long-term investment (preferring bank deposits to any other savings products (Mager, 2016) and are even subject to investment lumpenization process (Anesyanz, 2011), the issue of increasing financial literacy and awareness of equity market instruments is in focus for the Russian Government, making it introduce new taxation rules for domestic tax residents to stimulate demand for investment products in 2015 (Ivanova, 2014). The changes that have been implemented in the Russian Federal Law "On Securities Market" and the Tax Code of the Russian Federation since January 1, 2015 brought into legal action two new terms that are Individual Investment Account itself and Tax Rebate on Investment.

All the amendments connected to the concept of Individual Investment Accounts were reflected in Section 10.3 of the Federal Law "On Securities Market". Individual Investment Accounts are assumed to be a kind of brokerage accounts with preferential tax treatment that are serviced by brokerage houses or asset management companies separately from other brokerage service accounts held by an investor. Each investor is eligible to open just one Individual Investment Account and can contribute up to 1 Million Roubles annually on it, being free to allocate this funds in any security listed on Russian exchanges he/she likes by himself/herself or to transfer it into an asset management scheme his/her broker or asset manager provides within a minimum period of 3-years. In case of being unhappy with the quality of brokerage services or finding more attractive contractual conditions in any other professional securities market participating company, an investor is free to renegotiate it with more favourable terms and without losing time from his/her Individual Investment Account's opening.

The concept of time becomes crucial because of the principles of getting tax rebates from investment for 
such an account that are presented in Section 219.1 of the Tax Code of the Russian Federation. It identifies that investors have two possible types of rebates from using IIAs, depending on their own investment preferences:

Type A tax rebate (on the income) can be received by investor every year as a $13 \%$ cashback from his/her annual contribution on the Individual Investment Account, limited by the sum of 52 Thousand Roubles. This type of investment rebate implies to having a source of income in the current year that is subject to taxation.

Type B (on the result) applies to getting all the capital gain on your Individual Investment Account's operations free of taxation after the end of 3-years' time period of Individual Investment Account holding.

Since the period of this tax incentive implementation, several improvements in the existing framework were made, including the increase of a maximum annual contribution amount from 400 Thousand to 1 Million Roubles. Also, the intention of getting Individual Investment Accounts insured against any fraudulent practice or bankruptcy of brokerage houses or asset management companies get support from the Government of Russia in July 2017, while was discussed since 2015 for building of investors' trust and stimulating investment activity to be transferred to the financial market from banking products and from traditional brokerage accounts (noting that in 2016 the overall amount of contributions on IIAs reached 13 Billion Roubles, while the traditional accounts get nearly 23 times more fresh money (NAUFOR, 2016).

Next, the paper will concentrate more on the existing literature evidence on this tax incentive in Russia, both in the respect of its special characteristics and problems.

\section{LITERATURE REVIEW}

Prior studies by Russian researchers, which were conducted during the last 3 years, mostly outlined the differential characteristics of individual investment accounts itself and comparing with its international analogues.

Koren, Goloyad, Ivashinnikova (2016) state the main objectives that are expected to be met by implementing such tax incentive as individual investment accounts, including expected increase in tax revenue and money inflow in the national economy on long-term horizon, as well as better financial literacy among the Russians. Tropina (2015) and Bulgakova (2016) clarify the legal status of individual investment accounts and give a definition to investment tax rebates, highlighting both types of rebates and its target users: type A (rebate on the income) will be more interesting for those who try to optimize their basis of taxation (so may also actively use other types of tax rebates) and are looking for the return on investment exceeding an average deposit one, while type B (rebate on the result) is designed for experienced investors who have already used stock market for investment purposes and expect to earn profits from using an IIA which are higher than possible payback in the option A. Mager (2016) adds a quantitative proving to this point, comparing these two tax rebate types with different rate of return on investment, deriving the rate of return at which the investor should better prefer the tax rebate type $B$ to tax rebate type $A$. All three authors suggest that the investment tax rebate on the investor's income appears to be the main tool to drain deposit users to IIAs.

Comparing with US Individual Retirement Accounts (IRA) and British Individual Savings Accounts (ISA), Russian tax incentives are more closely based on Japanese Nippon Individual Savings Accounts (NISA). Both of these tax-beneficial accounts (1) are aimed to solve the problem of national equity markets' undersaturation, but in differing perspectives, as most part of the Russian market trade turnover is created by banks (NAUFOR, 2016), while Tokyo Stock Exchange faces dominance of foreign investors that create nearly $67 \%$ of the overall trade turnover (comparing with Japanese individual investors' contribution of $23 \%$ (Bank of Japan, 2017); (2) appear to be an efficient alternative to the popular among the countries' households bank deposits, as they accounted for 882,293 Billion Yen, or 51.4 percent of total Japanese household financial assets, in the year of NISA launch (2014) (Japan Securities Dealer Association, 2016) and 16.25 Trillion Roubles, or 62.5 percent of total Russian household financial assets, in the year of 2015 (Radyugin, Abramov, Akshentseva, 2016); (3) are not treated like a part of the country's pension system, unlike IRA and ISA; (3) can be opened just one per investor, being similar to ISAs in this respect; (4) have specific timeframes ( 3 years for Russia and 5 years for Japan) that limit possible money withdrawals by the condition of losing all the tax advantages; (5) have no 
minimum amount required to open it (both for IIA, NISA, IRA and ISA, just maximum limits for initial and subsequent contributions - 1 Million Roubles and 400 Thousand Roubles for IIA, respectively), equity market opportunities become available for investor with any initial capital, even enough for buying just one instrument (Armidonova, Devlet-Geldy, 2016).

Hence, there are certain properties that make a real difference of individual investment accounts, including unlimited time of its possible use on the expiry of three years and nearly no restrictions to the possible instruments that can be included in an investor's IIA portfolio (with the single exception for them to be listed on any exchange situated in Russia) (Surovneva, 2016).

Since individual investment accounts have all the same management mechanics as traditional brokerage accounts, researchers discussed portfolio management principles in their studies. Lepeshkina (2015) emphasizes the possibility of investment selfmanagement, as well as delegation of investment decision-making to a broker, for IIA users who can choose their investment strategy in accordance with their risk appetite. The researcher covers some aspects of IIA portfolio management from behavioral economics, particularly talking about rational expectations theory and adaptive expectations theory. Biryukov (2015) considers possible IIA investment strategies and provides his own suggestions about basic principles of conservative investment strategy formation, taking into account IIA specific characteristics, and provide possible range of return investors can possibly get by following such strategy. Troekurov (2016) also discusses investment strategies for long-term investment on IIA, being more concerned about investment portfolio composition and its dependence on current Russian equity market conditions and the local currency stability.

Also, several authors underline possible difficulties for individual investment accounts' popularization, such as (1) overall low propensity for long-term investment which is common for Russian residents (since the proportion of deposits with the period over three years in overall household deposit structure reaches just $4.99 \%$ in 2017 (Bank of Russia, 2017) and seems to be relatively insufficient as a direct target amount for transferring it into stock market; (2) low customer confidence in equity market instruments due to negative experience of losing money in pyramid investment schemes in 1990s and lack of current market and economic stability (Glagoleva, 2015); (3) the main alternative instruments to bank deposits are governmental, municipal and high-rated corporate bonds with high duration that are vulnerable to an interest rate risk, especially in periods of the Bank of Russia key rate changes (Papin, 2015); (4) irrelevance of individual investment accounts for non-working social categories (such as students, householders, pensioners) and sole proprietors because of having no personal income tax payable for getting tax rebate from income (type A) and overall lack of financial literacy for using tax rebate from results (type B) (Biryukov, 2015); (5) investors' unwillingness to make difficult steps for getting tax rebates, including filling of a tax return for and communicating with local tax authorities (Bezsmertnaya, 2016).

Because of the point that individual investment accounts are a new tax incentive for Russian financial market, there is a limited amount of literature about its potential users' investment preferences and risk-return profile, so this research will add to the existing research in this respect. Also, it adds to the overall research of investment habits of the Russians, as such analysis is most commonly conducted for banking, not investment products (Makovetskaya, 2015), or just among existing investors, not potential ones (Moscow Exchange, 2016).

The methodology of the research in this field will be addressed in more detail next.

\section{RESEARCH DESIGN AND METHODS}

Since the field of analysis is quite new for Russia, the use of both qualitative and quantitative research design is appropriate. In order to explore the relationship between investment preferences and different sociodemographic factors. In order to examine the effect of such factors, this study collects random samples of 200 citizens of Russia, who do not work for any securities industry participant and act as a potential end user of tax incentive like IIA, using an anonymous questionnaire (both online and paper-blanked) designed in the view of independent and control variables and logically divided into two parts: one of them consists of personal questions aimed to identify the demographic group of the respondent and consists of 5 questions, including the respondent's age, gender, marital status, level of education and work place, while the other one is designed for getting the picture of the investment profile and includes 10 questions about the investment behavior of respondents in terms of 
previous investment experience (both connected with saving and multiplying the respondent's capital), potential amount, time horizon and style of investment management, as well as instrument preferences in terms of asset class and currency of denomination. The questionnaire can be found in Appendix 1.

To concentrate the researcher's attention on the main questions about typical habits of Russian investors, several research hypotheses have been formulated.

H1. An Investor's Age has a direct effect on his/hers Expected Return and corresponding Level of Risk from using an Individual Investment Account.

The researchers decided to test the age-factor hypothesis, assuming the evidence from several academic papers on the age aspect of Russian households' economic behaviour (Kapeliush, 2007; Rossinskaya, 2007; Mezhevov, 2014) which state that Russians' savings and investment activity has a positive correlation with investors' age group, even taking into account the practice of obligatory savingsbank books' use for pension transferring purposes (mainly outside the central part of Russia). Kapeliush (ibid.) also identifies the age group from 30 to 60 years old as the most active savers and investors.

H2. An Investor's Gender has a direct effect on his/hers Expected Return and corresponding Level of Risk from using an Individual Investment Account.

The gender hypothesis is quite a contradictory issue: some researchers state there is no real difference in the investment aims among men and women (Makovetskaya, 2015), but others identify significant differences in economic behaviour models of different genders (Filatova, 2007; Romanova, 2014), making men more focused in terms of day-by-day budget management and women more savingsoriented.

H3. Most of the investors prefer to invest funds on their Individual Investment Accounts for the Lesser Time Period of the options presented - 3 years.

H4. Most of the investors prefer to invest their funds on their Individual Investment Accounts in financial instruments denominated in Roubles.

Both hypotheses 3 and 4 are based point that Individual Investment Accounts are aimed to be an advantageous alternative for bank deposits and, according to the latest Central Bank of the Russian Federation data on the bank clients fund distribution, there is a significant edge of Rouble deposits over Foreign Currency ones $(77.5 \%$ versus $22.5 \%)$ and short-term deposits over medium- and long-term ones (having $60.26 \%$ of all clients' money allocated for less than a year and $35.45 \%$ - for the period from 1 to 3 years).

H5. The Younger an investor is, the More Instruments he/she is aware of or is willing to include in the investment portfolio on an Individual Investment Account.

H6. The more educated an investor is, the More Instruments he/she is aware of or is willing to include in the investment portfolio on an Individual Investment Account.

Several authors stated the need of raising the Russian's financial literacy level overall (Baranov, 2016; Bezsmertnaya, 2016). Even the joint effort of the Central Bank of the Russian Federation and the World Bank within the project of "enhancing financial literacy and developing financial education in the Russian Federation" has not changed the overall financial knowledge of Russians since 2013: recent survey of Global Financial Literacy Excellence Center showed that just $38 \%$ of adults in Russia are financially literate, that is in-line with the results for such countries as Kenya, Serbia and United Arab Emirates, while the major advanced economies have significantly better situation with financial literacy $(67 \%$ - for UK citizens, $66 \%$ - for German respondents, $57 \%$ - for US residents and $43 \%$ for Japan).

Still, since the National Association of Financial Information Research (2015) results showed that recent school graduates and students are solving simple tasks in financial mathematics even better than most of experienced respondents, we suggest to check this within our respondents' group.

Next we come to the analysis of the information received within the questionnaire interviews performed.

\section{DESCRIPTIVE ANALYSIS OF RESEARCH RESULTS}

The overall structure of sample group involved in the questionnaire research in accordance with its main independent variables presented by demographic factors can be foreseen in Table 1.

The sample is presented mostly by female respondents, who were nearly 2.5 times more active 
than male research audience, what seems to be quite a common practice for social studies in Russia (Mikhailova, 2015). Taking into account the point that the majority of responses were received using methods like emailing and social networks questionnaire distribution, the most frequently occurring age groups were Russians aged from 18 to 35 years' old, representing more than a half of the answer series. The group whose interests were presented in the smallest way were pre-retirement and retirement age respondents, the proportion of those amounted just to $11.5 \%$.
In terms of marital status, there seems to be a significant dominance of married and coupled respondents $(55 \%)$, while divorced Russians are presented relatively less $(9.5 \%)$, as well as widowers, who did not find themselves as the participants of this research.

The respondents' overall educational level appears to be rather high, with $71.5 \%$ of the participants having complete or incomplete university degree (noting that there are $14.5 \%$ of students involved in the research). Still, the respondents with specialized college education and secondary school education are

Table 1: Structure of the Sample Group in Accordance with Demographic Factors

\begin{tabular}{|c|c|c|c|c|}
\hline & Frequency & Percent & Valid Percent & Cumulative Percent \\
\hline \multicolumn{5}{|l|}{ Gender } \\
\hline Male & 57 & 28,5 & 28,5 & 28,5 \\
\hline Female & 143 & 71,5 & 71,5 & 100 \\
\hline Total & 200 & 100 & 100 & \\
\hline \multicolumn{5}{|l|}{ Age Group } \\
\hline $18-25$ & 51 & 25,5 & 25,5 & 25,5 \\
\hline $25-35$ & 56 & 28 & 28 & 53,5 \\
\hline $35-45$ & 39 & 19,5 & 19,5 & 73 \\
\hline $45-55$ & 31 & 15,5 & 15,5 & 88,5 \\
\hline $55-65$ & 20 & 10 & 10 & 98,5 \\
\hline Total & 200 & 100 & 100 & \\
\hline \multicolumn{5}{|l|}{ Marital Status } \\
\hline Single & 71 & 35,5 & 35,5 & 35,5 \\
\hline Married/with a partner & 110 & 55 & 55 & 90,5 \\
\hline Separated/divorced & 19 & 9,5 & 9,5 & 100 \\
\hline Total & 200 & 100 & 100 & \\
\hline \multicolumn{5}{|l|}{ Education Level } \\
\hline Incomplete High School & 4 & 2 & 2 & 2 \\
\hline High School & 20 & 10 & 10 & 12 \\
\hline College & 33 & 16,5 & 16,5 & 28,5 \\
\hline Incomplete University & 9 & 4,5 & 4,5 & 33 \\
\hline University & 134 & 67 & 67 & 100 \\
\hline Total & 200 & 100 & 100 & \\
\hline \multicolumn{5}{|l|}{ Occupation } \\
\hline Temporarily unemployed & 6 & 3 & 3 & 3 \\
\hline Student & 29 & 14,5 & 14,5 & 17,5 \\
\hline Housewife & 9 & 4,5 & 4,5 & 22 \\
\hline Salaried & 138 & 69 & 69 & 91 \\
\hline Self-employed & 13 & 6,5 & 6,5 & 97,5 \\
\hline Retired & 5 & 2,5 & 2,5 & 100 \\
\hline Total & 200 & 100 & 100 & \\
\hline
\end{tabular}


Question: "Do you have an individual investment account?"

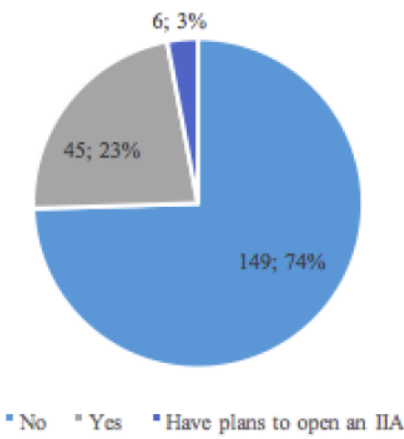

Question: "What sum of the initial contribution is comfortable for you to be deposited on your individual investment account?"

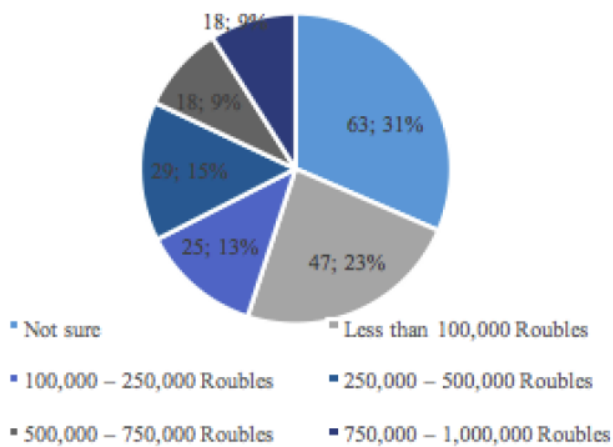

Figure 1: The respondents' answers breakdown for questions on a IIA current ownership and a sum of possible initial contribution.

engaged, giving us a picture of the differences in investment preferences depending on the level of specific knowledge, especially meaning financial one. In addition, most part of the respondents are currently employed or run his/her own business $(75.5 \%$ in total).

A promising point for the research was that nearly a quarter of the respondents have an Individual Investment Account (with no details about whether there is any money contributed on such an account) or have ongoing plans to open such an account that appears to be quite optimistic, taking into account relatively small exposure of this incentive among Russians. But coming to the sum of capital potentially available for investing, the picture changes, facing $31 \%$ of participants being unsure about their potential ability to invest for 3 or more years and the other $36 \%$ ready to contribute up to 250,000 Roubles a year. Adding some more $14.5 \%$ who have up to 500,000 Roubles to invest for the potentially higher returns, there is rather small amount of people potentially interested in investing up to $1,000,000$ Roubles that is the maximum amount of contribution from 2017, changed from the level of 400,000 Roubles.

The issue of a consequent contribution makes potential investors even more confused, since $43.5 \%$ of the respondents are tend to consider their ability to put more money on their individual investment accounts as quite uncertain, while the other $12.5 \%$ are sure that they do not feel comfortable to contribute any more (amounting $56 \%$ in total for this two categories). Respondents are tend to contribute less subsequently, mainly because of being unsure about such a long-time
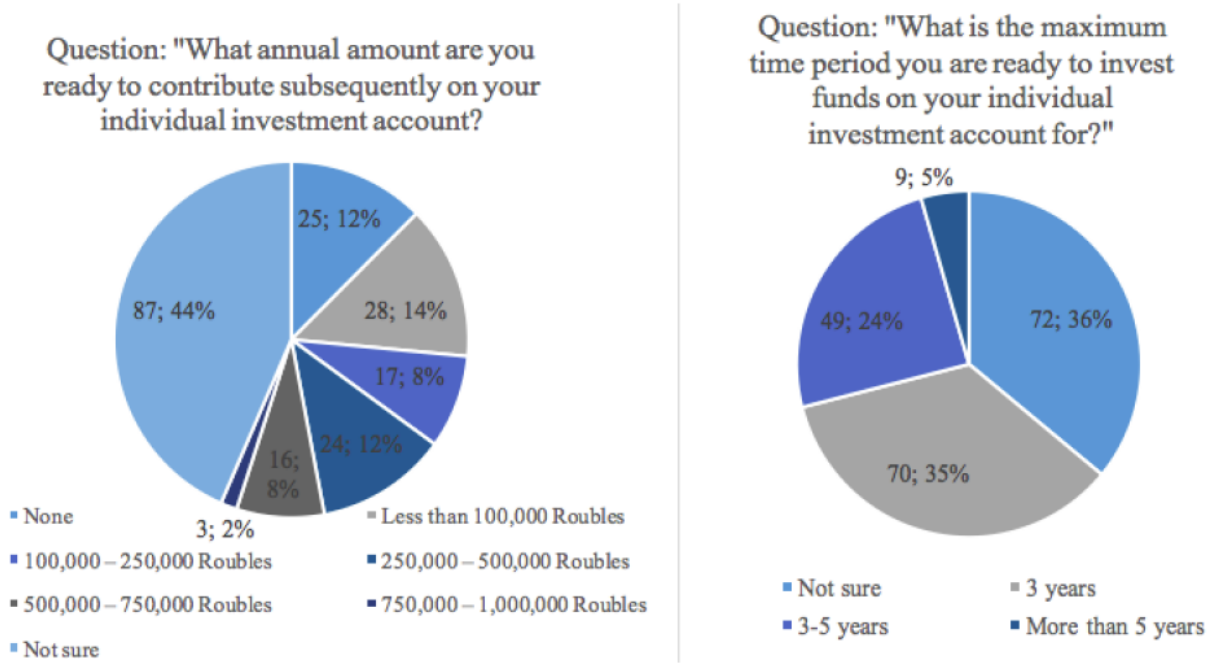

Figure 2: The respondents' answers breakdown for questions on a sum of possible subsequent contribution and a maximum investment period. 
Table 2: Structure of the Sample Group in Accordance with an Expected Annual Return Rate

\begin{tabular}{|c|c|c|c|c|}
\hline & Frequency & Percent & Valid Percent & Cumulative Percent \\
\hline \hline Not sure & 76 & 38 & 38 & 38 \\
\hline Less than 10\% (low risk) & 20 & 10 & 31 & 48 \\
\hline $10-20 \%$ (limited risk) & 62 & 31 & 10 & 89 \\
\hline $20-30 \%$ (moderate risk) & 20 & 10 & 11 & 100 \\
\hline More than 30\% (high risk) & 22 & 100 & 100 & \\
\hline Total & 200 & & \\
\hline
\end{tabular}

horizon of investment $(36 \%$ of respondents are not sure about it and more than a half of the rest think of 3 years as maximum).

The problem with identifying an appropriate type of tax deduction for the investor's Individual Investment Account, that was stated by many Russian brokerage houses, was confirmed by the majority of respondents, since $52 \%$ of them do not know exactly which one will suit them better in accordance with their investment strategy. The rest part of respondents divided into a larger group of those who prefer to use tax rebate on contribution (type A) $-35 \%$, and a smaller one (13\%) consisting of the potential type $B$ rebate on income users.

Going to the most important dependent variable within this research presented by the expected annual rate of return with the corresponding level of risk, there also seems to be a case with more than a third part of respondents not sure about their return expectations from using Individual Investment Accounts. Also, there is foreseen to be a prevailing group of participants expecting to get the annual return of $10-20 \%$ (which seems to be reasonable even together with the type $A$ annual tax rebate of $13 \%$ ), while the rest respondents are equally distributed between low-risk investment opportunities and some moderate to high-risk ones (as it is presented in Table 2).

In terms of the currency of investment denomination, we see that the national currency is the most popular currency of investment among the respondents $(39.5 \%)$, but it should be noted that, even though Dollars and Euros are not as much popular as Roubles individually ( $10.5 \%$ and $5 \%$, respectively), they were often mentioned by investors together (so fall into the category of "several currencies").

The question about the type of portfolio management surprisingly raise very little questions and uncertainty, making the participants mostly choose to potentially make any investment decisions by themselves $(62 \%)$, leaving those who prefer to rely on a professional opinion in a minority (36\%).

\section{CORRELATION ANALYSIS OF RESEARCH RESULTS}

Pearson correlation matrix is presented below in the Table 3, giving a picture of the correlation among the variables, both dependent and independent.
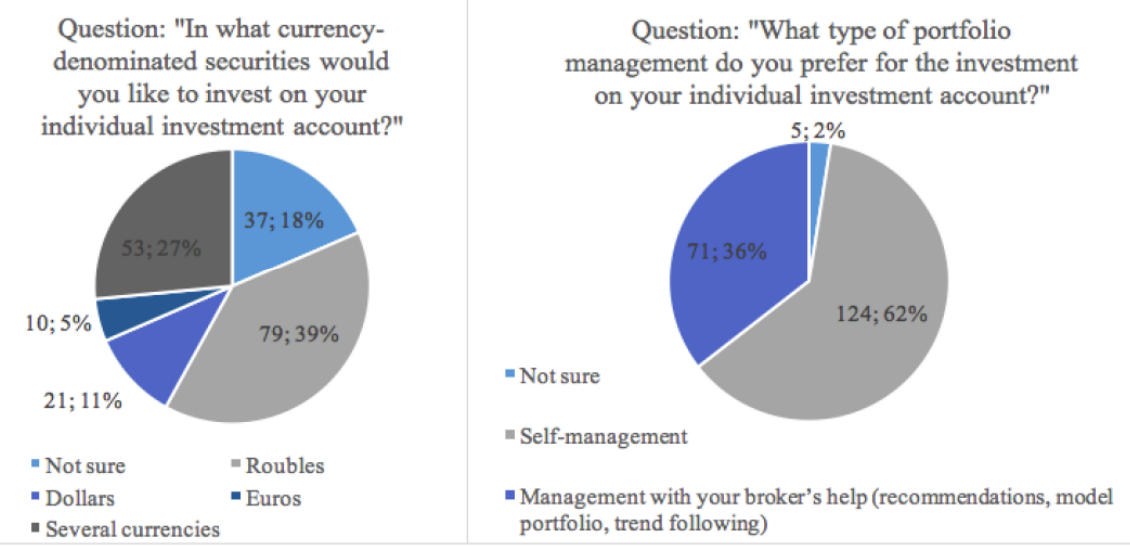

Figure 3: The respondents' answers breakdown for questions on a currency of investment and a preferred type of portfolio management. 


\begin{tabular}{|c|c|c|c|c|c|c|c|c|c|c|c|c|c|c|c|c|}
\hline$\frac{z}{z}$ & $\frac{\tilde{m}}{i}$ & ஜ & $\stackrel{N}{\stackrel{2}{0}}$ & $\begin{array}{l}\widetilde{0} \\
\infty \\
0 \\
0\end{array}$ & $\begin{array}{l}\mathscr{8} \\
i \\
i\end{array}$ & ָัo & $\begin{array}{l}\text { to } \\
\text { : }\end{array}$ & $\begin{array}{l}0 \\
\stackrel{0}{0} \\
b \\
0 \\
0\end{array}$ & 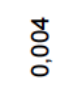 & $\stackrel{\leftrightarrow}{\circ}$ & $\begin{array}{l}\text { 艿 } \\
0 \\
0\end{array}$ & $\begin{array}{l}0 \\
0 \\
0\end{array}$ & $\frac{*}{\frac{*}{0}}$ & $\frac{\text { D }}{0}$ & $\frac{*}{\frac{*}{y}}$ & 商 \\
\hline$\frac{\alpha}{\alpha}$ & 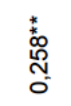 & 0 & $\begin{array}{l}0 \\
0 \\
0 \\
0\end{array}$ & 今. & $\begin{array}{l}\bar{z} \\
0 \\
0\end{array}$ & $\begin{array}{l}\stackrel{0}{\circ} \\
0 \\
0\end{array}$ & $\begin{array}{l}\frac{*}{0} \\
\frac{0}{\circ} \\
\end{array}$ & $\begin{array}{l}0 \\
0 \\
0\end{array}$ & $\stackrel{5}{\frac{N}{0}}$ & $\begin{array}{l}\stackrel{\infty}{\circ} \\
\stackrel{0}{0} \\
0\end{array}$ & $\begin{array}{l}\overline{8} \\
\text { : }\end{array}$ & $\stackrel{N}{0}$ & 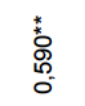 & 0 & 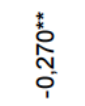 & 0 \\
\hline $\begin{array}{l}\underline{\alpha} \\
\stackrel{\underline{5}}{\underline{n}} \\
\underline{\underline{n}}\end{array}$ & $\begin{array}{l}\text { 卷 } \\
\stackrel{N}{N} \\
\text { o. }\end{array}$ & 0 & $\begin{array}{l}8 \\
: \\
1\end{array}$ & 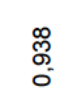 & o̊ & $\begin{array}{l}\mathscr{8} \\
\& \\
0\end{array}$ & 蔏 & סू & $\begin{array}{l}\text { ơ } \\
0 \\
0 \\
i\end{array}$ & ల్ల్ర & 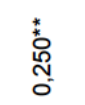 & 。 & $\begin{array}{l}\text { * } \\
\text { 8. } \\
0 \\
0 \\
0 \\
0\end{array}$ & 0 & 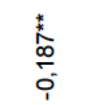 & : \\
\hline$\underset{0}{\stackrel{\alpha}{\alpha}}$ & $\begin{array}{l}\text { : } \\
\text { స్ํํ } \\
\text { : }\end{array}$ & $\bar{\alpha}$ & $\underset{0}{\frac{5}{0}}$ & $\stackrel{9}{\frac{9}{6}}$ & $\begin{array}{l}\text { ò } \\
\text { i. }\end{array}$ & $\begin{array}{l}\bar{\delta} \\
\text { o. } \\
0\end{array}$ & $\frac{*}{0}$ & $\begin{array}{l}\text { ¿े } \\
\text { o. }\end{array}$ & $\frac{\bar{\sigma}}{0}$ & $\frac{\pi}{5}$ & 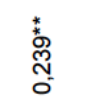 & $\bar{\delta}$ & \begin{tabular}{l} 
* \\
$\stackrel{8}{0}$ \\
\multirow{8}{0}{} \\
0 \\
0
\end{tabular} & 0 & 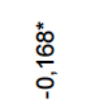 & $\stackrel{\hat{o}}{0}$ \\
\hline 吕 & 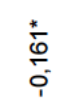 & $\begin{array}{l}\tilde{y} \\
\text { o. } \\
0\end{array}$ & $\frac{\sigma}{0}$ & $\frac{g}{\frac{9}{0}}$ & $\overline{0}$ & $\frac{8}{6}$ & 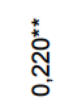 & סे & $\stackrel{+}{\frac{\pi}{0}}$ & $\frac{\hat{0}}{0}$ & $\begin{array}{l}* \\
\frac{*}{\circ} \\
\frac{8}{0}\end{array}$ & : & $\begin{array}{l}\text { *o } \\
\frac{*}{\sigma} \\
0 \\
0\end{array}$ & 0 & 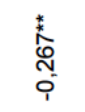 & 0 \\
\hline 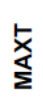 & 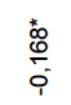 & $\hat{\tilde{O}}$ & 兽 & 察 & $\begin{array}{l}N \\
\stackrel{N}{0} \\
i \\
i\end{array}$ & 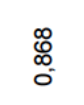 & 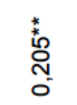 & $\begin{array}{l}\text { पे } \\
\text { Oे }\end{array}$ & סू & $\because$ & 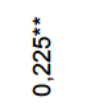 & $\bar{o}$ & $\begin{array}{l}\frac{*}{*} \\
\frac{*}{8} \\
0\end{array}$ & 0 & 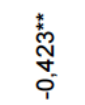 & 0 \\
\hline $\begin{array}{l}\text { U. } \\
\text { ڤ్ }\end{array}$ & $\bar{\delta}$ & $\begin{array}{l}\text { d } \\
\stackrel{0}{0} \\
0\end{array}$ & $\stackrel{\frac{N}{c}}{i=}$ & $\frac{⿱ 亠}{\sigma}$ & ồ & 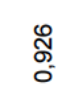 & , & 0 & $\frac{\text { on }}{\stackrel{0}{0}}$ & $\begin{array}{l}0 \\
0 \\
0\end{array}$ & 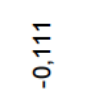 & $\frac{N}{c}$ & , 意 & 0 & - & \\
\hline$\underline{0}$ & 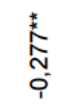 & 0 & $\begin{array}{l}\frac{*}{8} \\
\frac{8}{0}\end{array}$ & : & $\frac{\tilde{m}}{0}$ & : & $\frac{*}{\substack{* \\
m}}$ & o & $\begin{array}{l}\stackrel{*}{m} \\
\stackrel{m}{N} \\
\stackrel{m}{0}\end{array}$ & סั & 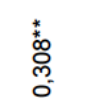 & ○ & - & & 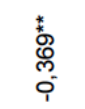 & 0 \\
\hline$\leqq$ & $\begin{array}{l}\bar{o} \\
\bar{o}\end{array}$ & 总 & $\begin{array}{l}\stackrel{0}{0} \\
0 . \\
i\end{array}$ & 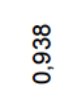 & $\stackrel{8}{\circ}$ & 怘 & $\begin{array}{l}\text { से } \\
\text { o. } \\
0\end{array}$ & 商 & 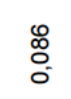 & 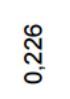 & - & & $\begin{array}{l}\text { vo } \\
\text { o. } \\
0 \\
0 \\
0 \\
0\end{array}$ & 0 & $\underset{i}{\bar{i}}$ & $\stackrel{5}{\frac{N}{0}}$ \\
\hline 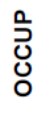 & $\frac{N}{i}$ & : & 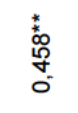 & 0 & 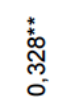 & o & 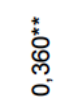 & 0 & - & & $\begin{array}{l}\mathscr{0} \\
\stackrel{0}{\circ}\end{array}$ & 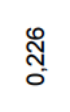 & $\underset{\substack{* \\
N}}{\stackrel{*}{N}}$ & ơ & 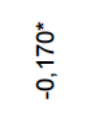 & $\begin{array}{l}0 \\
\stackrel{0}{0}\end{array}$ \\
\hline 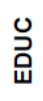 & tô & $\stackrel{\substack{\text { g } \\
0}}{0}$ & $\stackrel{m}{0}$ & $\begin{array}{l}\because \\
\vdots \\
0\end{array}$ & 兽 & : & - & & 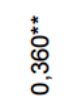 & 0 & $\begin{array}{l}\text { D. } \\
\stackrel{0}{0} \\
0\end{array}$ & 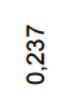 & $\frac{*}{*}$ & 0 & 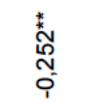 & 0 \\
\hline 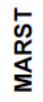 & o్ & 怘 & 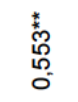 & 0 & - & & 兽 & 芯 & 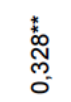 & 。 & $\stackrel{0}{0}$ & 孞 & $\frac{\tilde{m}}{0}$ & \% & ồ & $\begin{array}{l}\stackrel{0}{\mathscr{N}} \\
\stackrel{-}{0}\end{array}$ \\
\hline 岁 & $\begin{array}{l}\text { م } \\
0 \\
0 \\
i\end{array}$ & 总 & - & & $\begin{array}{l}\text { 靑 } \\
\text { 总 } \\
0\end{array}$ & 0 & $\stackrel{m}{\circ}$ & ष & 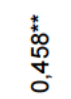 & $\circ$ & : & $\begin{array}{l}\infty \\
\stackrel{0}{0} \\
0\end{array}$ & $\frac{1}{8}$ & ஜ̊ & $\frac{N}{\stackrel{N}{c}}$ & $\stackrel{+}{\frac{\pi}{0}}$ \\
\hline 疍 & - & & $\begin{array}{l}\text { م. } \\
0 \\
0 \\
0\end{array}$ & 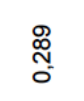 & o్ & $\begin{array}{c}\text { 总 } \\
\text { : } \\
0\end{array}$ & to & 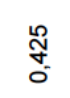 & $\stackrel{\sim}{\stackrel{\circ}{0}}$ & : & $\begin{array}{l}\bar{o} \\
0 \\
\end{array}$ & 芯 & 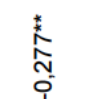 & 0 & $\overline{\mathrm{s}}$ & 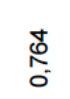 \\
\hline & 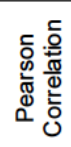 & 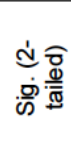 & 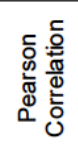 & 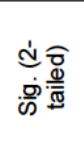 & 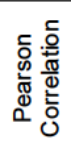 & 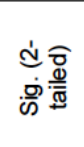 & 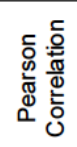 & 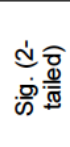 & 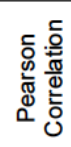 & 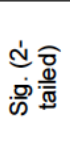 & 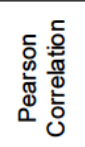 & 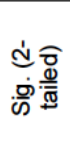 & 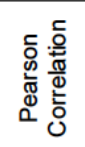 & 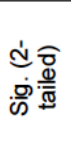 & 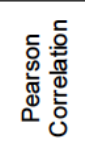 & 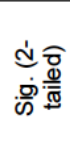 \\
\hline & 邑 & & 岁 & & $\begin{array}{l}\text { 怘 } \\
\frac{\tilde{\alpha}}{\Sigma} \\
\Sigma\end{array}$ & & 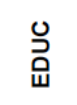 & & 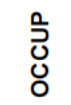 & & $\leqq$ & & $\underline{\underline{u}}$ & & 怘 & \\
\hline
\end{tabular}




\begin{tabular}{|c|c|c|c|c|c|c|c|c|c|c|c|c|}
\hline$\frac{z}{\Sigma}$ & $\begin{array}{l}\mathscr{0} \\
0 \\
0 \\
0\end{array}$ & 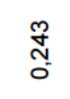 & 兽 & \begin{tabular}{l}
\multirow{2}{*}{} \\
J \\
\end{tabular} & s̄ & 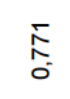 & 总 & 范 & $\frac{0}{0}$ & $\frac{5}{0}$ & - & \\
\hline$\underset{\alpha}{\alpha}$ & $\begin{array}{l}\text { : } \\
\text { : } \\
\text { O్ } \\
0\end{array}$ & 0 & $\begin{array}{l}\text { : } \\
\text { o. } \\
0 \\
0 \\
0\end{array}$ & 0 & 莺 & 0 & 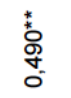 & 0 & - & & $\frac{\dddot{0}}{0}$ & $\frac{\hat{f}}{0}$ \\
\hline $\begin{array}{l}\frac{\alpha}{\underline{\underline{n}}} \\
\underline{\underline{\omega}}\end{array}$ & $\begin{array}{l}\text { 意 } \\
\text { o. } \\
0.0 \\
0\end{array}$ & 0 & 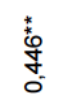 & 0 & 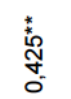 & 0 & - & & 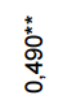 & 0 & 总 & 范 \\
\hline 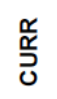 & $\begin{array}{l}\text { 意 } \\
\text { o. } \\
0.0\end{array}$ & 0 & $\begin{array}{l}\text { : } \\
\text { o. } \\
\text { o. } \\
0 \\
0\end{array}$ & 0 & - & & 莺 & 0 & 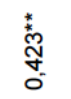 & 0 & $\begin{array}{l}\bar{\delta} \\
0 \\
0\end{array}$ & 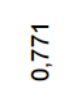 \\
\hline 염 & 曾 & 0 & - & & 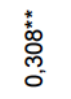 & 0 & 系 & 0 & 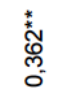 & o & זٓ & $\begin{array}{l}0 \\
\frac{1}{4} \\
0\end{array}$ \\
\hline$\underset{\mathbf{b}}{\mathbf{x}}$ & - & & 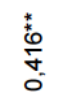 & 0 & $\begin{array}{l}\text { : } \\
\text { 总 } \\
0 \\
0 \\
0\end{array}$ & 0 & $\begin{array}{l}\text { vo } \\
\text { O⿱丷⿹弔㇒ } \\
0 \\
0\end{array}$ & 0 & \begin{tabular}{l} 
: \\
\multirow{W}{*}{} \\
0 \\
0
\end{tabular} & 0 & $\begin{array}{l}0 \\
0 \\
0\end{array}$ & $\stackrel{\text { I্ }}{\mathrm{N}}$ \\
\hline 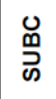 & , & 0 & , 胥 & 0 & 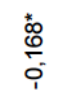 & ڤે & 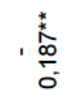 & $\stackrel{\infty}{\circ}$ & , & 。 & 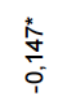 & $\begin{array}{l}\hat{o} \\
\text { o. } \\
\text { o. }\end{array}$ \\
\hline$\underline{\mathfrak{u}}$ & $\begin{array}{l}\frac{*}{8} \\
\frac{8}{0} \\
0\end{array}$ & 0 & $\begin{array}{l}\text { 巻 } \\
\frac{\sigma}{t} \\
0 \\
0\end{array}$ & 0 & 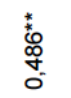 & 0 & $\begin{array}{l}\text { 总 } \\
\text { 点 } \\
0 \\
0\end{array}$ & 0 & $\begin{array}{l}\text { 嘉 } \\
\text { 品 }\end{array}$ & 0 & $\frac{\underbrace{*}}{0}$ & ปั \\
\hline$\leqq$ & 营 & ¿े & $\frac{*}{8}$ & : & 苾 & s. & 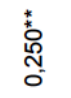 & 0 & $\begin{array}{l}\bar{g} \\
\text { : }\end{array}$ & $\stackrel{\sim}{o}$ & 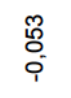 & $\begin{array}{l}0 \\
\stackrel{0}{0}\end{array}$ \\
\hline $\begin{array}{l}0 \\
\text { Õ } \\
0 \\
0\end{array}$ & $\bar{o}$ & $\because$ & $\underset{0}{\stackrel{5}{c}}$ & $\frac{0}{0}$ & $\frac{\overline{0}}{0}$ & $\frac{\mathrm{H}}{0}$ & 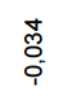 & 芯 & $\stackrel{\hat{\sigma}}{\epsilon}$ & $\begin{array}{l}\infty \\
\stackrel{0}{0} \\
0\end{array}$ & $\begin{array}{l}\text { ¿े } \\
\text { o. }\end{array}$ & $\stackrel{\mathscr{O}}{\circ}$ \\
\hline O & 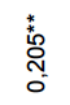 & $\begin{array}{l}\text { पे } \\
\text { Oे }\end{array}$ & 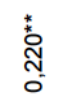 & õ & $\frac{*}{\stackrel{*}{0}}$ & స్ & 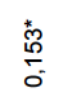 & סू. & $\frac{*}{6} \frac{*}{6}$ & : & do & $\begin{array}{l}0 \\
0 \\
0 \\
0 \\
0\end{array}$ \\
\hline $\begin{array}{l}5 \\
5 \\
\frac{n}{4} \\
\Sigma \\
\Sigma\end{array}$ & $\begin{array}{l}N \\
\stackrel{N}{i} \\
0\end{array}$ & $\begin{array}{l}\stackrel{0}{0} \\
\stackrel{0}{0} \\
0\end{array}$ & $\bar{o}$ & $\stackrel{8}{\circ}$ & o̊ & চ. & 。̊ & 惫 & $\begin{array}{l}\bar{y} \\
0\end{array}$ & 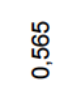 & $\begin{array}{l}8 \\
i \\
\end{array}$ & 音 \\
\hline 岁 & 吕 & 交 & $\frac{\mathrm{s}}{0}$ & $\frac{g}{0}$ & $\underset{c}{\frac{F}{0}}$ & $\stackrel{9}{\frac{9}{5}}$ & $\begin{array}{l}0 \\
\text { o } \\
\end{array}$ & $\begin{array}{l}\infty \\
\stackrel{\infty}{0} \\
\stackrel{0}{0}\end{array}$ & $\begin{array}{l}m \\
0 \\
0\end{array}$ & 总 & $\stackrel{0}{0}$ & $\begin{array}{l}\widetilde{0} \\
\mathbb{\infty} \\
0\end{array}$ \\
\hline \multirow[t]{3}{*}{ 疍 } & 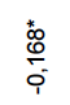 & $\begin{array}{r}\hat{o} \\
0\end{array}$ & $\frac{*}{6}$ & $\begin{array}{l}\widetilde{\Xi} \\
0 \\
0\end{array}$ & 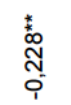 & סे & 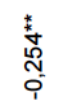 & 0 & 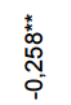 & 0 & 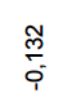 & ஜ: \\
\hline & 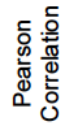 & 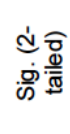 & 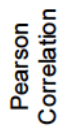 & 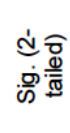 & 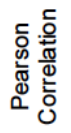 & 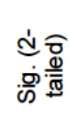 & 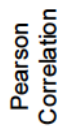 & 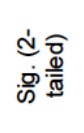 & 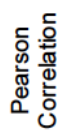 & 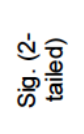 & 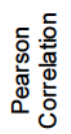 & 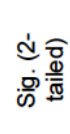 \\
\hline & $\begin{array}{l}\text { b } \\
\Sigma\end{array}$ & & Щ् & & $\frac{\alpha}{\tilde{\alpha}}$ & & $\begin{array}{l}\underline{\alpha} \\
\stackrel{\underline{w}}{\underline{0}}\end{array}$ & & $\frac{\alpha}{\alpha}$ & & $\frac{z}{z}$ & \\
\hline
\end{tabular}


It was detected that Expected annual rate of return has significant relation to several independent variables, including Gender and Educational Level. Gender presents a negative relation to Expected rate of return at the significance level of 0.01 , meaning that male investors are tend to require greater level of annual returns, comparing to women. Besides, investor's Education level as an independent variable has a positive relation at the significance level of 0.01 , implying that investors with higher education level typically expect higher annual returns from their investment.

As for maximum period of investment, there are several significant relations with independent variables detected: Gender presents a negative interaction to Marginal time horizon of investors using IIAs at the significance level of 0.05 , making male investors ready to invest money for longer time that women. Also, investor's education has a positive relation to his/her expected rate of return at the significance level of 0.01 , making more educated investors typically invest for longer time as maximum.

The relation of several independent variables and the respondents' identified potential amounts of initial and subsequent contributions on their IIAs. Most of the independent variables, excluding the respondents' Marital status, have a significant relation to such a variable as an amount of IIA Initial contribution (all at the level of 0.01 ). Its amount is associated to be higher for female respondents and less for male ones, also increases with person's moving into adulthood and due to progress in his/her level of education. For Subsequent contribution variable, a significant influence is detected just with the respondents' Education and Occupation: they are negatively related at the significance level of 0.01 and 0.05 , respectively.

The number of instruments investors consider for their capital allocation on IIAs has a significant negative interaction with Gender and Education level. This means that male respondents are tend to choose more instruments of investment, comparing to female ones, while more well-educated respondents choose greater variety of potential asset classes (and vice versa).

It should be noted that all of the dependent variables have dependent relation to each other. For instance, an amount of Initial contribution is positively related to Maximum period of investment, Number of potentially interesting for investment purposes instruments and to Expected annual return from investment, while negatively correlated with an amount of Subsequent contribution. Hence, an amount of Subsequent contribution is significantly negatively related to both Marginal period of investment, Number of asset classes potentially used and Expected annual return. The variable connected with Maximum time of investment has a significant positive relation to Number of potentially interesting Instrument groups and Expected annual return, while Number of asset types is positively related to Expected rate of return. All the interrelations listed out appear to be significant at the 0.01 level.

Talking about multiple linear regression analysis that was also performed, it showed that all 5 demographic factors (Gender, Age, Marital Status, Education and Occupation) used to explain the changes in expected rate of return, account just for $8.9 \%$ of the variability of it, while one independent variable (Gender) accounts for $6.2 \%$ and two used variables (Gender and Education) - for $10.2 \%$ of the variability of expected rate of return.

\section{RESULTS DISCUSSION}

The hypotheses testing and the relationships identification that was expected to be obtained within this research are conducted within this chapter. The findings of this paper are summed up and compared with the previous studies' evidence below.

\section{H1. Individual investor's age and expected annual return from holding an Individual Investment Account}

Hypothesis 1 predicts that investor's age has a direct effect on his/her expected return and corresponding level of risk from use of Individual Investment Accounts. This relation was expected to be negative, making older investors less appetite for risk than younger ones. However, it was concluded that the interrelation between these two variables is positive, but seems to be statistically insignificant since the Chisquare statistic of 29.598 calculated using the Crosstabulation Table 4 is less than critical levels for $\mathrm{f}=20$ both at the confidence levels of 0.01 (37.566) and 0.05 (31.41). This leads to the conclusion that Investor's age is not related to Expected annual return from IIA investment and hypothesis one is rejected. This result does not agree with the similar prior studies of Makovetskaya (2015), stating the growth of low-risk instruments attractiveness with the increase in investors' age, and Kapeliush (2007) appealing on the 
Table 4: Crosstabulation of Age and Expected Annual Return Showing Percentages within each Age Group

\begin{tabular}{|c|c|c|c|c|c|c|c|}
\hline \multirow{2}{*}{ Expected Annual Return } & \multicolumn{7}{|c|}{ Age } \\
\cline { 2 - 7 } & $\mathbf{1 8 - 2 5}$ & $\mathbf{2 5 - 3 5}$ & $\mathbf{3 5 - 4 5}$ & $\mathbf{4 5 - 5 5}$ & $\mathbf{5 5 - 6 5}$ & above 60 & Total \\
\hline \hline Not sure & $18(35.29 \%)$ & $21(37.5 \%)$ & $14(35.9 \%)$ & $17(54.84 \%)$ & $6(30 \%)$ & $0(0 \%)$ & $76(38 \%)$ \\
\hline Less than 10\% (low risk) & $5(9.8 \%)$ & $8(14.29 \%)$ & $5(12.82 \%)$ & $1(3.23 \%)$ & $1(5 \%)$ & $0(0 \%)$ & $20(10 \%)$ \\
\hline $10-20 \%$ (limited risk) & $17(33.33 \%)$ & $18(32.14 \%)$ & $14(35.9 \%)$ & $6(19.35 \%)$ & $6(30 \%)$ & $1(33.33 \%)$ & $62(31 \%)$ \\
\hline $20-30 \%$ (moderate risk) & $3(5.88 \%)$ & $8(14.29 \%)$ & $4(10.26 \%)$ & $2(6.45 \%)$ & $3(15 \%)$ & $0(0 \%)$ & $20(10 \%)$ \\
\hline More than 30\% (high risk) & $8(15.69 \%)$ & $1(1.79 \%)$ & $2(5.13 \%)$ & $5(16.13 \%)$ & $4(20 \%)$ & $2(66.67 \%)$ & $22(11 \%)$ \\
\hline Total & $51(100 \%)$ & $56(100 \%)$ & $39(100 \%)$ & $31(100 \%)$ & $20(100 \%)$ & $3(100 \%)$ & $200(100 \%)$ \\
\hline
\end{tabular}

same point. Hence, the outcome partly corresponds to Kapeliush, who adds the point on the existing interest in stocks among investors, who are older than 50 years' old.

Since a significant part of respondents $(38 \%)$ was not sure about the rate of return they are expecting to get from their investment on the Individual Investment Account, there appears to be a strong negative correlation $(-0.877)$ between the age group and the number of respondents uncertain in terms of the expected annual return (making older investors more determined). This result is confirmed by several studies on savings and investment activity in Russia conducted by Kapeliush (2007) and Makovetskaya (2015) found that the age factor has a direct influence on investment activity (meaning having a defined investment strategy) of the Russians.

H2. Individual investor's gender and expected annual return from holding an Individual Investment Account

Hypothesis 2 examined investors' Expected annual return to their Gender. According to the correlation analysis conducted above in this chapter, there is a significant negative relation (the correlation of $-0,258$ at the confidence level of 0.01 ) between an investor's
Gender and his or her Return expectations, making male investors require higher returns, comparing to women, as it can be foreseen in the Table $\mathbf{5}$.

This does not go counter to the existing research of Makovetskaya (2015), since the most commonly occurring Expected return level is the same for both genders, but it also extends the findings of Filatova (2007) and Romanova (2014) on the differences in behaviour models and stating men's appeal for higher returns with correspondingly higher risks. Also, in contrast to the Kapeliush (2007) position that women are the most active and concerned savers, this research results say that female respondents are less sure about what returns are they expecting to get from their investment comparing to male ones $(42.66 \%$ versus $26.32 \%$ ).

\section{H3. Individual investor and time horizon of his/her investment on an Individual Investment Account}

Hypothesis 3 suggested that the majority of investors are potentially able to invest their money on an Individual Investment Account for as short time as it is possible, making 3-years-period the most popular one among other options. Explained by the short-term nature of savings in Russia, this point partly confirms this hypothesis, since $35 \%$ of respondents holding this

Table 5: Crosstabulation of Gender and Expected Annual Return Showing Percentages within each Age Group

\begin{tabular}{|c|c|c|c|}
\hline \multirow{2}{*}{ Expected Annual Return } & \multicolumn{2}{|c|}{ Gender } & \multirow{2}{*}{ Total } \\
\cline { 2 - 4 } & Male & $61(42.66 \%)$ & $76(38 \%)$ \\
\hline \hline Not sure & $15(26.32 \%)$ & $16(11.19 \%)$ & $20(10 \%)$ \\
\hline Less than $10 \%$ (low risk) & $4(4.02 \%)$ & $46(32.17 \%)$ & $62(31 \%)$ \\
\hline $10-20 \%$ (limited risk) & $16(28.07 \%)$ & $11(7.69 \%)$ & $20(11 \%)$ \\
\hline More than 30\% (high risk) & $9(15.79 \%)$ & $9(6.29 \%)$ & $22(11 \%)$ \\
\hline Total & $13(22.81 \%)$ & $143(100 \%)$ & $200(100 \%)$ \\
\hline
\end{tabular}


Table 6: Crosstabulation of Gender and Maximum Period of Investment Showing Percentages within each Age Group

\begin{tabular}{|c|c|c|c|}
\hline \multirow{2}{*}{ Maximum Period of Investment } & \multicolumn{2}{|c|}{ Gender } & \multirow{2}{*}{ Total } \\
\cline { 2 - 4 } & Male & Female & $72(36 \%)$ \\
\hline \hline Not sure & $15(26.32 \%)$ & $57(39.86 \%)$ & $70(35 \%)$ \\
\hline 3 years & $19(33.33 \%)$ & $51(35.66 \%)$ & $49(24.5 \%)$ \\
\hline 3-5 years & $19(33.33 \%)$ & $30(20.98 \%)$ & $9(4.5 \%)$ \\
\hline More than 5 years & $4(7.02 \%)$ & $5(3.5 \%)$ & $200(100 \%)$ \\
\hline Total & $57(100 \%)$ & $143(100 \%)$ & \\
\hline
\end{tabular}

position present the main part of defined investors (still, the major fraction belongs to those who are not sure). This result correlates with the research of Kapeliush (2007), who mentioned the existing inconvenience in the foreseeing future financial stability among her research respondents that makes two thirds of them choose demand and one-year deposits from all the variety of banking products.

This research adds to the existing evidence in terms of cross-analysis of such maximum period of investment and several demographic variables that have a significant influence on it, presented by negative relation to Gender (Table 6) and positive one to Education characteristics (Table 7).

Since male investors are tend to invest for longer, we see a small dominance of women above men $(35.66 \%$ versus $33.33 \%)$ on a three-years' time horizon, which is eliminated on longer prospects. Still, female respondents represent the major part of research participants that are unsure about their Marginal investment period.

Taking into consideration the positive correlation of potential investors' Marginal investment horizon to Education level, it is common to find out the 3-years' time horizon among the largest group of respondents presented by University Graduates (which is accompanied by those respondents who have not completed their university education yet). Potential investors who have lower educational level, are assumed to have more doubts about the marginal investment time. This point also corresponds to the research of Kapeliush (2007), who sees the reason for this phenomenon both in having a wealth status corresponding to education and being more informationally adaptive to communicate with financial institutions about savings and investment.

H4. Individual investor and his/her preferred currency of investment on an Individual Investment Account

Hypothesis 4 states that potential users of Individual Investment Accounts presented by current bank depositors are expected to replace their current traditional bank products by IIA portfolios consisting of Rouble-denominated assets. The overview of the research participants' responses is presented in the Table 8.

As the share of respondents potentially willing to include Rouble instruments in their investment portfolio reached $39.5 \%$ of all those who participated in the research, hypothesis 4 may be accepted, even not taking into account the investors who included Roubles in the list of desirable currencies while replying with the

Table 7: Crosstabulation of Education Level and Maximum Period of Investment Showing Percentages within each Age Group

\begin{tabular}{|c|c|c|c|c|c|c|}
\hline \multirow{2}{*}{$\begin{array}{l}\text { Maximum Period of } \\
\text { Investment }\end{array}$} & \multicolumn{5}{|c|}{ Education Level } & \multirow[b]{2}{*}{ Total } \\
\hline & $\begin{array}{c}\text { Incomplete High } \\
\text { School }\end{array}$ & High School & College & $\begin{array}{l}\text { Incomplete } \\
\text { University }\end{array}$ & University & \\
\hline Not sure & $4(100 \%)$ & $10(50 \%)$ & $16(48.48 \%)$ & $2(22.22 \%)$ & $40(29.85 \%)$ & $72(36 \%)$ \\
\hline 3 years & $0(0 \%)$ & $8(40 \%)$ & $6(18.18 \%)$ & $5(55.56 \%)$ & $51(38.06 \%)$ & $70(35 \%)$ \\
\hline $3-5$ years & $0(0 \%)$ & $2(10 \%)$ & $9(27.27 \%)$ & $2(22.22 \%)$ & $36(26.87 \%)$ & $49(24.5 \%)$ \\
\hline More than 5 years & $0(0 \%)$ & $0(0 \%)$ & $2(6.06 \%)$ & $0(0 \%)$ & $7(5.22 \%)$ & $9(4.5 \%)$ \\
\hline Total & $4(100 \%)$ & $20(100 \%)$ & $33(100 \%)$ & $9(100 \%)$ & $134(100 \%)$ & $200(100 \%)$ \\
\hline
\end{tabular}


Table 8: Structure of the Sample Group in Accordance with a Preferred Currency of Investment

\begin{tabular}{|c|c|c|c|c|}
\hline & Frequency & Percent & Valid Percent & Cumulative Percent \\
\hline \hline Not sure & 37 & 18,5 & 18,5 & 18,5 \\
\hline Roubles & 79 & 39,5 & 39,5 & 58 \\
\hline Dollars & 21 & 10,5 & 10,5 & 68,5 \\
\hline Euros & 10 & 5 & 5 & 73,5 \\
\hline Several currencies & 53 & 26,5 & 100,5 & 100 \\
\hline Total & 200 & 100 & & \\
\hline
\end{tabular}

answer «Several currencies». The respondents' group attributed to this answer is worth some comments, since it shows the existing interest of Russian investors to Asian currencies, including Japanese Yen (8 respondents) and Chinese Renminbi (1 respondent), that has not been mentioned in any recent papers.

H5 and H6. Individual investor's age \& level of education and number of instruments he/she is aware of or is willing to include in an IIA investment portfolio

Hypothesis 5 suggests that there is a negative relation between Investor's age and Number of potentially attractive instrument classes for him or her. Taking into consideration the correlation analysis provided above in this chapter, there seems to be no significant relation between Investor's age and Number of instruments he or she is aware of while investing money on his or her Individual Investment Account. That is why this hypothesis is rejected.

Hence, the corresponding hypothesis 6 appeals to the point that respondents with higher level of education are expected to be more aware of different financial market instruments and are willing to use the, for their own investment purposes on Individual Investment Accounts. In accordance with the correlation analysis provided above in the chapter, there seems to be a significant positive relation (the correlation of 0,153 at the confidence level of 0.05 ) between investor's Education level and Number of asset classes listed by him or her for potential inclusion on an IIA. This leads us to a conclusion that higheducated investors are associated with larger number of instrument types in their portfolios, as it presented in the Table 9.

As it can be seen from the Table 9, Maximum number of investment asset classes included in the portfolio of those who did not finish High School is limited by one, High School and College graduates are aware and willing to invest in 4 asset classes as maximum, while University graduates are definitely aware of more investment opportunities (up to 11 asset classes) and do know well the principles of portfolio diversification (though, incomplete University graduates

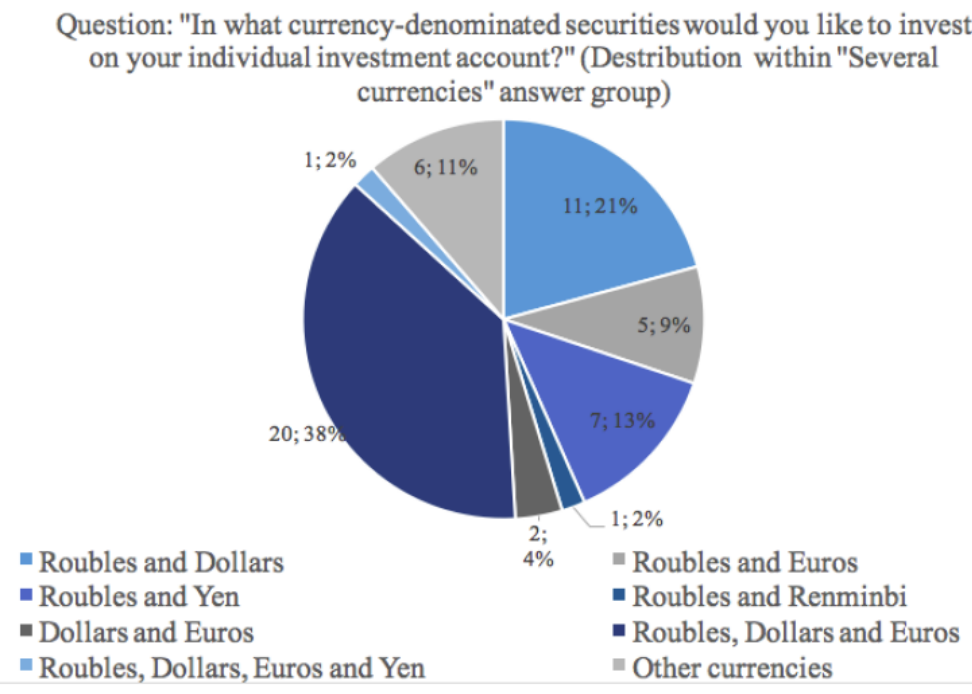

Figure 4: The respondents' opinion breakdown for questions on a currency of investment (for the answer "several currencies"). 
Table 9: Crosstabulation of Education Level and Number of Potentially Attractive Instrument Classes Showing Percentages within each Age Group

\begin{tabular}{|c|c|c|c|c|c|c|}
\hline \multirow{2}{*}{$\begin{array}{l}\text { Number of } \\
\text { Instruments }\end{array}$} & \multicolumn{5}{|c|}{ Education Level } & \multirow{2}{*}{ Total } \\
\hline & Incomplete High School & High School & College & Incomplete University & University & \\
\hline 0 & $3(75 \%)$ & $10(50 \%)$ & $14(42.42 \%)$ & $3(33.33 \%)$ & $42(31.34 \%)$ & $72(36 \%)$ \\
\hline 1 & $1(25 \%)$ & $5(25 \%)$ & $7(21.21 \%)$ & $4(44.44 \%)$ & $38(28.36 \%)$ & $55(27.5 \%)$ \\
\hline 2 & $0(0 \%)$ & $1(5 \%)$ & $10(30.30 \%)$ & $0(0 \%)$ & $31(23.13 \%)$ & $42(21 \%)$ \\
\hline 3 & $0(0 \%)$ & $3(15 \%)$ & $1(3.03 \%)$ & $2(22.22 \%)$ & $14(10.45 \%)$ & $20(10 \%)$ \\
\hline 4 & $0(0 \%)$ & $1(5 \%)$ & $1(3.03 \%)$ & $0(0 \%)$ & $4(2.99 \%)$ & $6(3 \%)$ \\
\hline 5 & $0(0 \%)$ & $0(0 \%)$ & $0(0 \%)$ & $0(0 \%)$ & $3(2.24 \%)$ & $3(1.5 \%)$ \\
\hline 7 & $0(0 \%)$ & $0(0 \%)$ & $0(0 \%)$ & $0(0 \%)$ & $1(0.75 \%)$ & $1(0.5 \%)$ \\
\hline 11 & $0(0 \%)$ & $0(0 \%)$ & $0(0 \%)$ & $0(0 \%)$ & $1(0.75 \%)$ & $1(0.5 \%)$ \\
\hline Total & $4(100 \%)$ & $20(100 \%)$ & $33(100 \%)$ & $9(100 \%)$ & $134(100 \%)$ & $200(100 \%)$ \\
\hline
\end{tabular}

are aware of 1 to 3 asset types). This makes the researcher approve this hypothesis, which has the results that agree to those stated by Kapeliush (2007) with the reference on Russian university graduates as the most active group of banking products' users, and by Bezsmertnaya (2016), with her emphasize on the current university graduates as the main driver of the future financial market development (in terms of money inflow).

\section{CONCLUSION}

This paper investigated the relationship between sociodemographic characteristics and the individual's investment preferences for long-term investment on Individual Investment Accounts. In this research, the demographic factors represented by respondents' age, gender, marital status, level of education and occupation act as independent variables, while investment preferences in terms of an amount of potential investment, its time horizon and expected annual return are considered to be dependent variables. The data for the research was collected using online and physical questionnaires that were sent to potential investors via email and were also spread through professional social networks and forums. The responses of 200 participants were analyzed with the help of descriptive statistics, correlation matrices and regression models built using IBM Statistic Analysis Software Solution called SPSS Statistics.

The results showed that the investor's age has no relation to the return from investment he/she is expecting to get annually, while the age of investor is negatively correlated to the investor's certainty about the expected return preference. Also, since the investor's gender in negatively correlated to his/her return expectations, male investors tend to require higher returns than women. What is more, the majority of respondents are not sure about the maximum time horizon they are ready to invest for, while those who're defined in their preferences typically choose the shortest 3-years-period. There also exists a positive correlation of potential investors' marginal investment horizon to education level. The number of instruments the investor is aware of does not have any relation to his/her age, but seems to be positively correlated to the education level. Additionally, Rouble investment opportunities appear to be the most desired ones, while a significant amount of people may be interested in Dollar-, Euro- and Asian-Currency-Nominated instruments for money allocation purposes.

\section{APPENDIX}

\section{Appendix 1}

This survey is designed to find out what kind of investment products are in demand among different categories of potential (or current) individual investment accounts' users in Russia (depending on their gender, age, investment experience, risk appetites, etc.). 
There is no right or wrong answer. This study is voluntary. If you decide to complete this survey, please be sure to answer all questions as they are important for accurate evaluation of this study.

Your name is not required and your responses will be kept confidential by the researchers.

Thank you for agreeing to participate in the study

\section{Read and answer each of the following questions carefully for accurate evaluation. Circle the answer that best represents your opinion.}

1. What is your gender?

- Male

2. What is your age?

- $18-25$

- $25-35$

- $\quad 35-45$

3. What is your marital status?

- Single

- Married/with a partner

4. What is your education level?

- Elementary school

- High school

4. What is your occupation?

- Student

- Temporarily unemployed

- Housewife

6. Which of this investment products have you ever used?

Choose at least one option

- Bank deposits

- Coins and/or Precious Metals

- Brokerage accounts

7. Do you have an individual investment account?

- Yes

- Have plans to open
- Mutual fund units

- $\quad$ Other (please specify)

- Self-employed

- Retired
- College

- University

- Salaried

- No 
8.What sum of the subsequent contribution is comfortable for you to be deposited on your individual investment account?

- Less than $100,000 \mathrm{~F}$

- $100,000-250,000 P$

- $250,000-500,000$ P
- $\quad 500,000-750,000$ F

- $750,000-1,000,000 P$

- Not sure

9. What annual amount are you ready to contribute subsequently on your individual investment account?

- None

- Less than $100,000 \mathrm{~F}$

- $100,000-250,000$ P

- $250,000-500,000$ P
- $\quad 500,000-750,000$ f

- $750,000-1,000,000 \mathrm{P}$

- Not sure

10. What is the maximum time period you are ready to invest funds on your individual investment account for?

- 3 years

- 3-5 years
- More than 5 years

- Not sure

11. What kind of tax deduction on your individual investment account would you like to use?

- Type $A$ - tax rebate at the rate of $13 \%$ of cash contribution (but not more than $52,000 P$ )

- Type B - zero income tax for capital gain on your individual investment account's operations

- Not sure

12. In what currency-denominated securities would you like to invest on your individual investment account?

- Roubles

- Dollars

- Euros
- Several currencies (please specify)

- Not sure

13. What instruments do you consider for potential investing on your individual investment account?

- Government bonds

- High-rated corporate, municipal and zero-coupon bonds

- Medium-rated corporate, municipal and zero-coupon bonds

- Low-rated bonds

- Blue chip stocks
- Growth stocks

- Small company stocks

- Speculative stocks

- Futures, options and other derivatives

- $\quad$ ETFs

- Foreign currencies

- Not sure 
14. What is an annual target expected return (with the corresponding level of risk) you wish to get from the investment on your individual investment account?

- Less than $10 \%$ (low risk)

- $10-20 \%$ (limited risk)

- $20-30 \%$ (moderate risk)

- More than $30 \%$ (high risk)

- Not sure

15. What type of portfolio management do you prefer for the investment on your individual investment account?

- Self-management

- Management with broker's help

\section{REFERENCES}

Anesyanz, Y.S. 2011. "The concept of general information space creating in the field of collective investment: the problem of demand." New Technology 1/2011: 34-36.

Armidonova, A.A. and G.K. Devlet-Geldy 2016. "Individual investment accounts as a new tool of the Russian financial market." Academic Herald 3:41:1-3.

Baranov, G. 2016. "Beginning Investors will not be allowed to take high risks" [online] Available at: https://www.kommersant.ru/ doc/3082043 [Accessed 20 May 2018].

Barrons.com. 2017. "Even Goldman Sachs Sees Virtue in Index Investing." [online] Available at: http://www.barrons.com/ articles/even-goldman-sachs-sees-virtue-in-index-investing1488491563 [Accessed 20 May 2018].

Bezsmertnaya, E.R. 2016. "Public Investments into Financial Market Tools: the Current State and Prospects of Development, Economics." Taxation. Law 9/6:17-25.

Biryukov, I.N. 2015. "Individual Investment Accounts as a mechanism of individual investors' attraction." Intelligence. Innovations. Investment 1:2017: 4-7.

boj.or.jp. 2017. "Bank of Japan Statistics."[online] Available at: https://www.boj.or.jp/en/statistics/index.htm/ [Accessed 20 May 2018].

Bulgakova, A.V. 2016. "Individual Investment Accounts as the main trend of households' investment activity development in 2015." Modern Challenges and Realities of Economic Development of Russia 1: 44-45.

cbr.ru. 2008. "Russian Financial Market Development Strategy through to 2020." [online] Available at: https://www.cbr.ru/ sbrfr/archive/fsfr/archive_ffms/ru/press/russia2020/strategy20 20/index.html [Accessed 20 May 2018].

cbr.ru. 2017. "Bank of Russia Statistics on the Amount of Assets allocated on deposits."[online] Available at: https://www.cbr. ru/statistics/print.aspx?file=bank_system/4-2-1a_17.htm\&pid =pdko_sub\&sid=dpbvf [Accessed 20 May 2018].

Filatova, A.F. 2007. "Psychology sex differences and gender psychology." Bulletin of Omsk University 1/2007: 125-130.

gflec.org. 2015. "Financial Literacy Around the World: Insights from the Standard \& Poor's Ratings Services Global Financial Literacy Survey."[online] Available at: http://gflec.org/wpcontent/uploads/2015/11/Finlit_paper_16_F2_singles.pdf [Accessed 20 May 2018]
Glagoleva, I.V. 2015. "Individual Investment Account as an innovative instrument tool on the Russian financial market." Infrastructure industries of the economy: problems and development prospects 11: 47-49.

Goloyad, A.N., E.A. Ivashinnikova, A.V. Koren, 2016. "Analysis of the new possibility of effective investment based on the use of Individual Investment Accounts." International Journal of Applied and Fundamental research 12 9: 1696-1699.

gov.uk. 2017. "Individual Savings Account (ISA) Statistics." [online] Available at: https://www.gov.uk/government/uploads/ system/uploads/attachment data/file/611387/Full Statistics Release_April_2017.pdf[Accessed 20 May 2018].

ici.org.2017. "2017 ICI RESEARCH PERSPECTIVE." [online] Available at: https://www.ici.org/pdf/per23-01.pdf [Accessed 20 May 2018].

Ivanova, M.A. 2014. "Innovations in Finance: Individual Investment Accounts as a way of the Russian financial market development." Actual Problems of Credit and Financial Institutions Development in the Russian Federation 1:87-90.

Ivanova, M.A., D. Petizheva 2015. "Individual Investment Accounts and how they impact on the Russian financial market." Economics and Management: Problems and Solutions 3 : 142-144.

jsda.or.jp. 2017. "Japan Securities Dealer Association Fact Book 2016." [online] Available at: http://www.jsda.or.jp/en/ securities-market-in-japan/files/FactBook2016(English) 20161230.pdf [Accessed 20 May 2018].

Kapeliush, A.K. 2015. "The sociodemographic structure of the Russian banking system, Finance and Credit". 7:247, 10-18.

kommersant.ru. 2017. "A Profitable Alternative." [online] Available at: https://www.kommersant.ru/doc/3362115/[Accessed 20 May 2018].

Lepeshkina, S.V. 2015. "Individual Investment Accounts as an instrument of retirement savings, Pension Fund: Traditions and Innovations." 1:2015: 67-71.

Mager, K.A. 2016. "Individual Investment Accounts: Current Effectiveness and Development Prospects, In the World of Science and Innovation." 1: 116-121.

Makovetskaya, E. 2015. "The influence of age and sex factors on patterns of economic behavior of households."UNIVERSUM: Economics and Legas Studies, 9-10(20): 2-3.

Mezhevov, A. 2014. "Socio-economic aspects of consumer behaviour." Marketing 1(134): 28-46. 
Mikhailova, A.V. 2015. "Economic behavior and everyday life of modern Russian women: a sociological view." Discussion 4(56): 79-90.

moex.com. 2017. "2015-2016 Individual Investment Accounts' Outlook." [online] Available at: http://fs.moex.com/f/7165/ otchet-iis-2015-2016.pdf [Accessed 20 May 2018].].

nacfin.ru. 2015. "The Russians about long-term investment: an allRussian Survey." [online] Available at: https://www.nacfin.ru/ rissiyane-o-dolgosrochnyx-investiciyax/ [Accessed 20 May 2018].

naufor.ru. 2016. "The Russian Equity Market: Facts and Highlights." [online] Available at: http://www.naufor.ru/download/pdf/ factbook/ru/RFR2016.pdf [Accessed 20 May 2018].

OECD. 1994. "Taxation and household saving, Organisation for Economic Co-operation and Development."Pp. 67-86.

Papin, V.V. 2014. "Individual Investment Account as the basis for long-term liabilities for stock market."Postgraduate 4: 138140.

Papin, V.V. 2017. "Individual savings encouragement as a prototype of the Individual Investment Accounts' incentive." Young Scientist 3(137): 387-389.

Radyugin, A., K. Abramov 2015. Investment Funds Economics. 1st Ed. Moscow: Delo Publishing 12-18.

Romanova, E.N. 2014. "Modelling economic behaviour of households in the financial market: gender aspect, Modern control technology." 1/2014: 408-419.
Rossinskaia, G.M. 2007. "To the methodology of economic analysis of consumer behaviour." Bulletin of Moscow University. The Economic Series 6/2007: 72-80.

Rot, A., A. Zaharov, Y. Mirkin, 2002. "Fundamentals of state regulation of the financial market." [online] Available at: http://www.mirkin.ru/_docs/book0401_035.pdf [Accessed 20 May 2018].

Russian Federal Law "On Securities Market" 1996 S 10.3

Surovneva, K.A. 2016. "Individual Investment Account as a modern tool for the Russian citizens' investment activity improvement." Modern trends of corporate and government management 1: 221-223.

Tax Code of the Russian Federation S 219.1

Troekurov, P.S. 2016. "Financial and Legal Basics of Individual Investment Accounts: the Experience of Developed Countries and Prospects in Russia." The Saratov State University Bulletin. New Issue. Economics. Management. Law 16-3: 326-332.

https://doi.org/10.18500/1994-2540-2016-16-3-326-332

Tropina, J.N. 2015. "Individual Investment Accounts and new investment opportunities for private investors, Economics and Society." 5-2(18): 201-205.

Tropina, J.N. 2015. "International Evidence on Individual Investment Accounts". Economics and Society 5-2(18): 212-216.

worldbank.org. 2017. "World Bank Open Data." [online] Available at: http://data.worldbank.org [Accessed 20 May 2018].

Received on 29-05-2018

Accepted on 19-08-2018

Published on 12-11-2018

DOI: https://doi.org/10.6000/1929-7092.2018.07.58

(C) 2018 Karpova and Panova; Licensee Lifescience Global.

This is an open access article licensed under the terms of the Creative Commons Attribution Non-Commercial License (http://creativecommons.org/licenses/by-nc/3.0/) which permits unrestricted, non-commercial use, distribution and reproduction in any medium, provided the work is properly cited. 